\title{
DNA:Anti-DNA Complexes: Their Detection in Systemic Lupus Erythematosus Sera
}

\author{
Ronald J. Harbeck, Emil J. Bardana, Peter F. Kohler, and \\ RONALD I. CARR \\ From the Section of Allergy and Clinical Immunology, National Jewish Hospital \\ and Research Center, Denver, Colorado 80206; the Division of Immunology \\ and Allergy, University of Oregon Medical School, Portland, Oregon 97201; \\ and the Division of Clinical Immunology, University of Colorado Medical \\ Center, Denver, Colorado 80220
}

A B S T R A C T Antibody to DNA was measured before and after treatment of systemic lupus erythematosus (SLE) sera with bovine pancreatic deoxyribonuclease (DNase I). In 11 of 15 cases of SLE with active renal disease there was a significant increase in DNA-binding after DNase digestion, while no such increase was noted in inactive SLE, normal controls or in patients with nonlupus renal disease. The significant rise in DNA-binding after digestion indicated that DNA had bound in vivo to the anti-DNA in these sera. A striking correlation between the occurrence of these complexes and disease activity was shown. In eight cases of SLE nephritis where serial blood samples were obtained, the greatest increase in DNA-binding after DNase digestion occurred at the time of the severest renal disease. In addition, serum from a case of SLE with acute cerebritis but without evidence of renal disease also had a significant rise in binding during the acute phase. This assay provides proof of the existence of circulating DNA: anti-DNA complexes in some cases of SLE and can also be used to measure an apparently critical parameter of disease activity.

\section{INTRODUCTION}

The role of DNA: anti-DNA complexes in the pathogenesis of certain cases of systemic lupus erythematosus $(\mathrm{SLE})^{1}$ nephritis has been previously suggested and considerable evidence supporting this possibility has ac-

Received for publication 26 June 1972 and in revised form 1 December 1972.

${ }^{1}$ Abbreviations used in this paper: ANA, antinuclear antibody; BGG, bovine gamma globulin; \% $\mathrm{P}$ corr, mean per cent of $0.1 \mu \mathrm{g}{ }^{125} \mathrm{I}-\mathrm{DNA}$ corrected for the normal control; PBS, phosphate-buffered saline. cumulated. DNA antibodies frequently occur in association with acute exacerbations of the disease, and DNA has been demonstrated occasionally in the sera of patients with acute lupus nephritis after disappearance of detectable anti-DNA (1-4). In addition, DNA has been shown along the glomerular basement membrane by immunofluorescence and antibodies with antinuclear specificities, including anti-DNA, have been eluted from postmortem SLE kidneys $(3,4)$. Recently it was demonstrated that circulating UV-DNA-anti-UV-DNA complexes can be nephrotoxic, supporting the likelihood that circulating complexes of anti-DNA with unaltered DNA may also be nephritogenic (5).

Although it has been assumed that in SLE DNA : antiDNA complexes are formed in the circulation before entrapment in the kidneys, only indirect evidence of circulating immune complexes in patients with this disease has been previously reported (6-9).

This study presents direct evidence of DNA:antiDNA complexes in certain SLE sera. The complexes of DNA and antibody to DNA were detected by measuring the binding by SLE sera of ${ }^{125}$ I-labeled native DNA ( ${ }^{125} \mathrm{I}$ DNA) before and after treatment of the sera with deoxyribonuclease (DNase I). If DNase digestion resulted in increased capacity of a serum to bind ${ }^{125} \mathrm{I}-\mathrm{DNA}$, the DNA-binding sites in the untreated serum must have been blocked in vivo by DNA, and therefore, the serum contained DNA:anti-DNA complexes. A significant increase in DNA-binding after such treatment of certain SLE sera occurred, and the relative increase showed a correlation with the disease activity of these patients.

\section{METHODS}

Subjects. Sera were obtained from 15 patients with active SLE nephritis, 13 SLE patients with no evidence of 
nephritis, 1 patient with SLE cerebritis without evidence of renal disease, 18 patients with active non-SLE nephritis, and 45 normal individuals. The 29 patients with SLE all had typical multisystem involvement and were classified as to activity of the disease according to the following criteria: (a) Active nephritis-abnormal urinalysis (proteinuria, hematuria, casts). Some patients also had an abnormal serum creatinine, creatinine clearance, and/or blood urea nitrogen (BUN). (b) No evidence of nephritis-normal urinalysis, serum creatinine, creatinine clearance, and BUN. In addition serial bleedings from nine of the SLE patients during exacerbation of the disease were studied.

Collection of sera. The blood was collected in sterile polypropylene disposable syringes (Monoject, Sherwood Industries, Deland, Fla.), allowed to clot at room temperature, and as soon as the clot formed, the cellular elements were removed by centrifugation. Sodium azide was added to give a final concentration of $0.1 \%$ and the serum was stored at $\mathrm{a}-20^{\circ} \mathrm{C}$.

Deproteinization of $D N A$. Native calf thymus DNA (Worthington Biochemical Corp., Freehold, N. J.) was deproteinized by a modification of a previously described procedure (10). A $250 \mu \mathrm{g} / \mathrm{ml}$ solution of DNA in $0.05 \mathrm{M}$ Tris $(\mathrm{pH}, 8.0), 0.001 \mathrm{M}$ ethylenediaminetetraacetic acid (EDTA), was extracted at room temperature for $1 \mathrm{~h}$ with an equal volume of water-saturated phenol containing $0.1 \%$ 8 -hydroxyquinoline. The aqueous phase was separated from the phenol phase by centrifugation at $1000 \times g$ for $5 \mathrm{~min}$ and re-extracted as above. The twice extracted aqueous phase

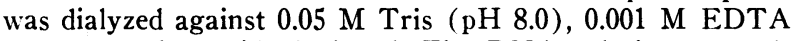
to remove the residual phenol. The DNA solution was adjusted to a density of $1.70 \mathrm{~g} / \mathrm{cm}^{3}$ by the addition of cesium chloride crystals ( $\mathrm{CsCl}$, optical grade, Harshaw Chemical Co., Solon, Ohio) and centrifuged at $33,000 \mathrm{rpm}$ in a Spinco 40.3 rotor (Spinco Div., Beckman Instruments, Inc., Palo Alto, Calif.) for $72 \mathrm{~h}$ at $4^{\circ} \mathrm{C}$. The purified DNA band was dialyzed against $0.1 \mathrm{M}$ acetate buffer, $\mathrm{pH}$ 5.0.

Labeling of DNA with ${ }^{125} I$. The deproteinized DNA was labeled with ${ }^{125} \mathrm{I}$ essentially as previously described (11). To $1 \mathrm{mg}$ DNA in $1 \mathrm{ml} 0.1 \mathrm{M}$ acetate buffer, $\mathrm{pH} 5.0$, the following reagents were added: $1 \mathrm{mg}$ thallic trichloride ( $\mathrm{K}$ and $\mathrm{K}$ Laboratories, Inc., Plainview, N. Y.), $16 \mu \mathrm{g} \mathrm{KI}$, and $1 \mathrm{mCi}$ radioactive iodine (carrier-free ${ }^{125} \mathrm{I}$, sodium salt in $0.1 \mathrm{M} \mathrm{NaOH}$, Cambridge Nuclear Corp., Cambridge, Mass.). The reagents were incubated together at $60^{\circ} \mathrm{C}$ for $1 \mathrm{~h}$ and dialyzed at $4^{\circ} \mathrm{C}$ against $1 \% \mathrm{KI}$ in $0.05 \mathrm{M}$ phosphate-buffered physiological saline (PBS), $\mathrm{pH} \mathrm{7.2,} \mathrm{for} 24 \mathrm{~h}$. Finally, the DNA was dialyzed against PBS for an additional $24 \mathrm{~h}$. The radioactive DNA had a specific activity exceeding $3 \times 10^{4} \mathrm{cpm} / \mu \mathrm{g}$.

Measurement of $D N A$ antibody. DNA antibody was measured using an ammonium sulfate precipitation assay previously described (12). The results are expressed as the mean per cent of $0.1 \mu \mathrm{g}{ }^{125} \mathrm{I}-\mathrm{DNA}$ which was bound by antibody and thus precipitable by half saturated ammonium sulfate corrected for the radioactivity in the precipitate of a normal serum (\% $\mathrm{P}$ corr) (13).

Preparation of soluble DNA: anti-DNA complexes in vitro. Quantitative precipitin reactions were performed with a serum from a patient with SLE to determine the amount of native DNA necessary for equivalence. Four times this amount was added to a sample of the serum to form soluble complexes in the zone of antigen excess. After 3 days incubation at $4^{\circ} \mathrm{C}$, the serum was centrifuged at $2000 \mathrm{rpm}$ for $1 \mathrm{~h}$ at $4^{\circ} \mathrm{C}$ to eliminate any precipitate which might have formed (none was visible). The supernatant serum containing soluble DNA: anti-DNA complexes was treated with DNase to determine the efficacy of the enzyme digestion in freeing blocked anti-DNA.

DNase digestion of serum. Two $0.3-\mathrm{ml}$ samples of each serum to be assayed were taken. An equal volume of PBS containing $60 \mu \mathrm{g}$ DNase I (Worthington Biochemical Corp.) and $1.8 \mu \mathrm{mol} \mathrm{MgCl}_{2}$ was added to the serum sample to be digested. To the undigested control sample, an equal volume of PBS was added. Both samples were mixed and incubated at $37^{\circ} \mathrm{C}$ for $1 \mathrm{~h}$. After an overnight incubation at $4^{\circ} \mathrm{C}$, the samples were incubated at $37^{\circ} \mathrm{C}$ for an additional $4 \mathrm{~h}$. Then $0.03 \mathrm{ml}$ of $1 \mathrm{M}$ tetrasodium ethylene diamine tetraacetic acid in distilled water was added to all samples. To obtain a funal serum dilution of $1: 10$ in the DNase digested sample, $2.4 \mathrm{ml}$ borate buffer $(0.01 \mathrm{M}$ borate, $0.15 \mathrm{M} \mathrm{NaCl}, \mathrm{pH} 8.3)$ were added. To the undigested control sample $2.4 \mathrm{ml}$ borate buffer containing $60 \mu \mathrm{g}$ DNase I and $1.8 \mu \mathrm{mol} \mathrm{MgCl}_{2}$ were added to obtain the same final serum dilution, DNase I and $\mathrm{MgCl}_{2}$ concentration as in the digested sample. The EDTA inhibited further DNase activity in the digested sample, prevented any digestion in the control, and prevented digestion of the ${ }^{125}$ I-DNA test antigen subsequently added. DNA antibody was then measured in five $0.5-\mathrm{ml}$ portions of the diluted digested and undigested serum. If a 1:10 dilution of the undigested serum bound more than $50 \%$ of the added antigen, the serum was diluted to bind $50 \%$ or less. The results were analyzed using the $t$ test for independent samples (14) to determine if there was a significant increase in binding after DNase digestion.

RNase digestion. Digestion with bovine pancreatic ribonuclease (RNase) (Worthington Biochemical Corp.) was carried out by adding $60 \mu \mathrm{g}$ of RNase to $0.3 \mathrm{ml}$ of a SLE serum known to show increased binding of ${ }^{125} \mathrm{I}$ after digestion with DNase. The enzyme, while degrading yeast transfer RNA (Miles Laboratories Inc., Kankakee, Ill.) in a standard assay system, had no effect on native calf thymus ${ }^{125}$ I-DNA under the same conditions.

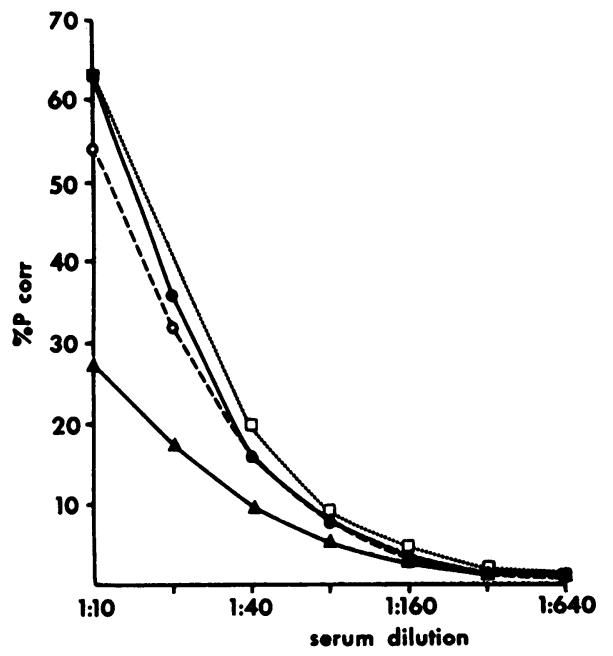

Figure 1 The effect of DNase digestion on the ${ }^{125} \mathrm{I}-\mathrm{DNA}$ binding of a SLE serum containing antibody to DNA as well as DNA : anti-DNA formed in vitro. SLE serum LT $(\square-. \square)$; SLE serum LT after digestion with DNase (๑-@); SLE serum LT containing soluble DNA : antiDNA complexes formed in vitro $(\boldsymbol{\Delta}-\boldsymbol{\Delta})$; SLE serum LT containing soluble DNA: anti-DNA complexes after digestion with DNase $(\mathrm{O}-\mathrm{O})$. 
Detection of DNA in the scrum. DNA in the serum was determined both immunologically and by the diphenylamine test as described previously (1).

\section{RESULTS}

Effect of DNase digestion on a serum containing DNA: anti-DNA complexes formed in vitro. As shown in Fig. 1, serum L.T. diluted $1: 10$ bound $63 \%$ of the ${ }^{125}$ I-DNA. The same dilution after digestion with DNase still bound $63 \%$. However, when sufficient DNA was added to the serum to form soluble DNA:anti-DNA complexes, the 1:10 dilution bound only $28 \%$. After this serum-DNA solution was digested with DNase, a $1: 10$ dilution bound 53\%. Thus in this "artificial" situation, DNase digestion raised the ${ }^{125}$ I-DNA-binding capacity back to $87 \%$ of that shown by the serum before addition of the DNA. The full titration curves show a similar effect (i.e., raising the binding level of the "blocked" serum back to that of the original serum).

Effect of RNase digestion on an SLE scrum containing DNA: anti-DNA complexes formed in vivo. As shown in Table I, RNase digestion had no significant effect on the ${ }^{125} \mathrm{I}$-DNA-binding by a serum from a patient with SLE. However, DNase digestion showed this serum contained DNA: anti-DNA complexes formed in vivo since the binding increased from $20 \%$ to $32 \%$.

Effect of DNase digestion on sera from patients with SLE, non-SLE nephritis, and normal controls. The results are summarized in Fig. 2 and representative results are given in Tables II-V.

As can be seen in Fig. 2, the \% P corr for 11 of 15 sera from patients with active SLE showed statistically significant absolute increases $(P<0.05)$ after DNase digestion of $4 \%-29 \%$. As shown in Table II, the relative increases for these sera, based on the binding by the sera before digestion, varied from $14 \%$ to $189 \%$. The other four sera had no significant change in binding.

There was also no significant change in any of the sera from the patients with inactive SLE (Table III and Fig. 2), the 18 with non-SLE nephritis (Table IV and Fig. 2) or the 45 normals (Table $\mathrm{V}$ and Fig. 2).

TABLE I

Comparison of the Effect of DNase and RNase Digestion on ${ }^{125} I-D N A-B i n d i n g$ Ability of an SLE Serum

\begin{tabular}{cccc}
\hline \multicolumn{4}{c}{$\%$ P Corr } \\
\cline { 2 - 4 } $\begin{array}{c}\text { Untreated* } \\
\text { serum }\end{array}$ & $\begin{array}{c}\text { Undigested } \\
\text { controlf }\end{array}$ & $\begin{array}{c}\text { R Nase } \\
\text { digested }\end{array}$ & $\begin{array}{c}\text { NNase } \\
\text { digested }\end{array}$ \\
\hline 20.0 & 21.0 & 20.7 & 31.9 \\
\hline
\end{tabular}

* No enzyme added.

†EDTA added before addition of IDNase to inactivate enzyme.

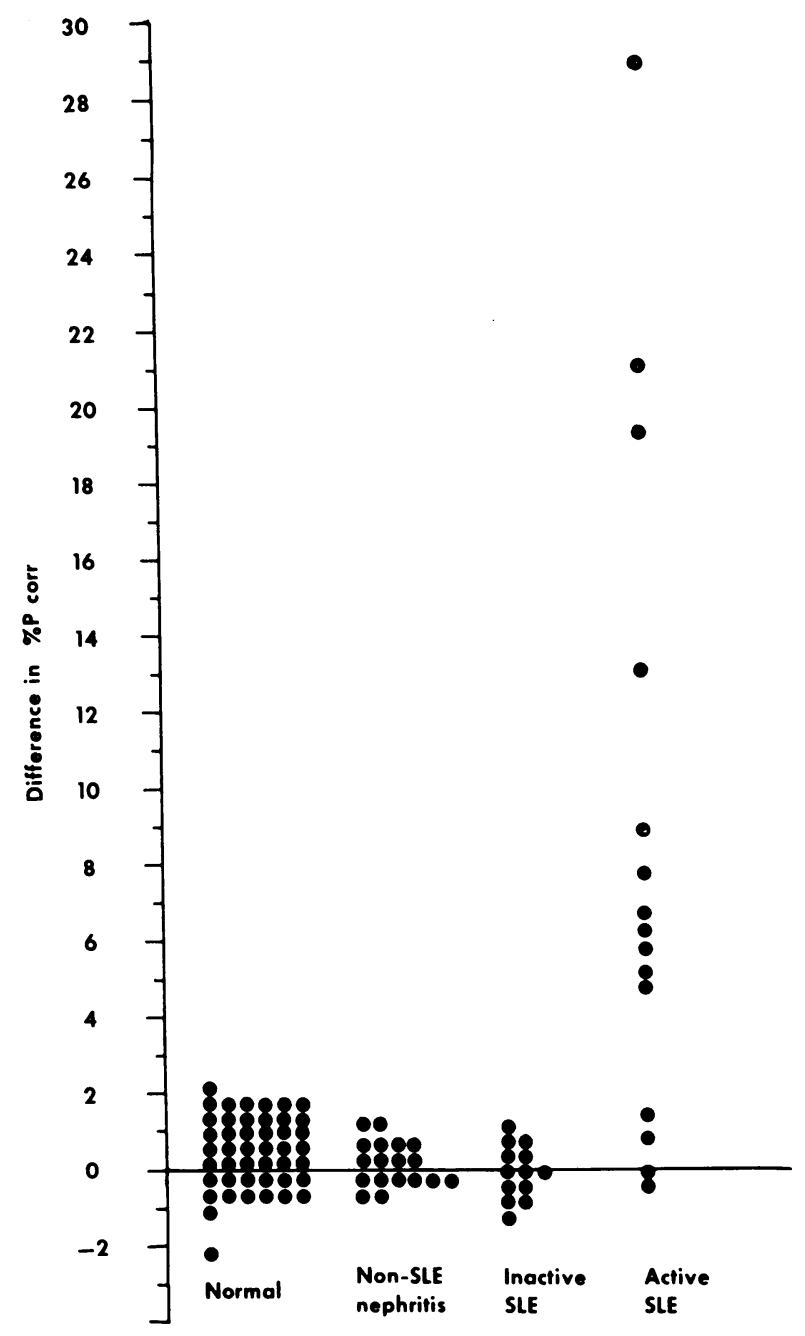

Figcre 2 Change in binding to ${ }^{125}$ I-DNA after DNase digestion of all sera from normal, non-SLE nephritis, inactive SLE nephritis, and active SLE nephritis patients.

In Table VI the mean change for each group is shown. Statistical examination of the four groups using the Kolmogorov-Smirnov one tail, two sample test (15) showed there was a significant difference in the increase in binding for the group with active disease compared with the inactive disease, non-SLE nephritis and normal groups $(P<0.01)$. There was no difference among the latter three groups $(P>0.05)$.

Serial studies on sera from nine SLE patients were performed. Fig. 3 depicts the course of a $24-y r-o l d$ female with a 3 yr history of SLE during an acute nephritis episode. Initially her serum exhibited considerable ${ }^{1 * 5}$ I-DNA-binding. Then, even though her apparent ability to bind ${ }^{125}$ I-DNA fell, she developed proteinuria and a high fever. However, DNA was detectable in her serum at this time, and digestion with DNase markedly raised the DNA-binding. The greatest increase coin- 
TABLE II

Representative Changes in Binding of ${ }^{125} I-D N A$ by Sera from Patients with Active SLE Nephritis after DNase Digestion

\begin{tabular}{|c|c|c|c|c|c|c|c|c|c|c|c|}
\hline \multirow[b]{2}{*}{ Patient } & \multicolumn{6}{|c|}{ Laboratory findings } & \multicolumn{5}{|c|}{ 125I-DNA-binding } \\
\hline & $\begin{array}{l}\text { Urine } \\
\text { protein }\end{array}$ & Casts* & $\begin{array}{c}24 \mathrm{~h} \\
\text { urine } \\
\text { protein }\end{array}$ & $\begin{array}{l}\text { Serum } \\
\text { creat. }\end{array}$ & BUN & $C^{\prime} 3 \ddagger$ & $\begin{array}{c}\% \mathrm{P} \S \\
\text { undigested }\end{array}$ & $\begin{array}{c}\% \mathrm{P} \\
\text { digested }\end{array}$ & $\begin{array}{l}\text { Diff. in } \\
\% P\end{array}$ & $\begin{array}{c}\text { Relative } \\
\text { change } \\
\text { in } P\end{array}$ & $P$ \\
\hline & & & $g$ & $\mathrm{mg} / 100 \mathrm{ml}$ & $m g / 100 \mathrm{ml}$ & $\mathrm{mg} / 100 \mathrm{ml}$ & & & & & \\
\hline 1 & $4+$ & $2+$ & 3.0 & NA\| & 18 & NA & $15.7 \pm 0.59$ & $44.6 \pm 0.79$ & 28.9 & $189 \%$ & $<0.001$ \\
\hline 2 & $3+$ & $3+$ & 0.7 & 0.9 & 60 & 45 & $42.9 \pm 0.6$ & $62.2 \pm 0.7$ & 19.3 & $45 \%$ & $<0.001$ \\
\hline 3 & $3+$ & $1+$ & 0.4 & 0.8 & 19 & 58 & $27.2 \pm 0.8$ & $39.9 \pm 2.0$ & 12.7 & $47 \%$ & $<0.001$ \\
\hline 4 & $3+$ & $3+$ & NA & 1.8 & 50 & 20 & $34.6 \pm 0.4$ & $43.5 \pm 0.4$ & 8.9 & $20 \%$ & $<0.001$ \\
\hline 5 & $2+$ & $1+$ & 0.9 & 0.8 & 16 & 198 & $38.0 \pm 1.0$ & $45.7 \pm 1.0$ & 7.7 & $21 \%$ & $<0.05$ \\
\hline 6 & $2+$ & $1+$ & 2.2 & 2.0 & 106 & 45 & $35.2 \pm 0.1$ & $41.9 \pm 1.0$ & 6.7 & $19 \%$ & $<0.01$ \\
\hline 7 & $4+$ & - & 0.7 & 0.8 & 14 & 115 & $6.2 \pm 0.4$ & $12.5 \pm 0.2$ & 6.3 & $101 \%$ & $<0.001$ \\
\hline 8 & $3+$ & $1+$ & NA & NA & 25 & 119 & $38.7 \pm 0.4$ & $43.9 \pm 0.4$ & 5.2 & $14 \%$ & $<0.001$ \\
\hline 9 & $1+$ & - & 0.4 & 1.3 & 23 & 105 & $47.4 \pm 0.3$ & $47.0 \pm 0.8$ & -0.4 & $-0.8 \%$ & $>0.05$ \\
\hline 10 & $3+$ & \pm & 2.7 & 0.8 & 9 & 150 & $22.4 \pm 0.5$ & $22.3 \pm 0.6$ & -0.1 & $-0.5 \%$ & $>0.05$ \\
\hline
\end{tabular}

$*-$, none; \pm , trace; $1+$, occasional; $2+$, moderate $3+$, many.

$\ddagger$ Normal range $90-175 \mathrm{mg} / 100 \mathrm{ml}$.

\| NA, not available.

I Mean of five samples \pm SE.

$\S \% \mathrm{P}$ corrected.

Sera one and three had DNA detectable by ouchterlony and diphenylamine analysis.

cided with the peak of the renal disease. At this time she was put on $80 \mathrm{mg}$ prednisone per day, the change in binding decreased, and the nephritis subsided.

Four other patients showed a similar course with acute renal disease developing concomitantly with a significant rise in ${ }^{125} \mathrm{I}-\mathrm{DNA}$-binding after DNase digestion. As the difference between the digested and undigested sera decreased, the nephritis subsided and normal urinalysis returned. Three patients had chronic lupus nephritis, and although they also exhibited a similar rise in binding after DNase digestion, at the time of acute exacerbations of their renal disease, urinalysis did not return to normal when the change in binding fell. In the ninth patient, a 15 -yr-old female, there was a general disease exacerbation (Fig. 4) characterized by a drop in the hematocrit to $34 \%$, an increase in the erythrocyte sedimentation rate to 60 , a low $\mathrm{C} 4$, a marked rise in ANA titer, and a fever of $40^{\circ} \mathrm{C}$. In addition, the patient became extremely lethargic, developed a severe headache, and marked nuchal rigidity. The opening pressure on a lumbar puncture at this time was $55 \mathrm{~cm}$ water, and the cerebrospinal fluid contained 344 white blood cells ( $84 \%$ polymorphs). Glucose and protein were normal. A diagnosis of SLE cerebritis was made and was subsequently supported when all cultures were negative. She was put on $60 \mathrm{mg}$ prednisone daily. Within 12 $\mathrm{h}$ there was considerable improvement in her central nervous system symptoms, and after $36 \mathrm{~h}$ there was no remaining neurologic abnormality. At this time there was an opening pressure of $30 \mathrm{~cm}$ of water on lumbar puncture; only 3 lymphocytes and protein and glucose were normal. As can be seen in Fig. 4, again there was

TABLE III

Representative Changes in Binding of ${ }^{125} I-D N A$ by Sera from Patients with Inactive SLE after DNAse Digestion

\begin{tabular}{|c|c|c|c|c|c|c|c|c|c|c|c|}
\hline \multirow[b]{2}{*}{ Patient } & \multicolumn{6}{|c|}{ Laboratory findings } & \multicolumn{5}{|c|}{${ }^{125}$ I-DNA-binding } \\
\hline & $\begin{array}{l}\text { Urine } \\
\text { protein }\end{array}$ & Casts & $\begin{array}{c}24 \mathrm{~h} \\
\text { urine } \\
\text { protein }\end{array}$ & $\begin{array}{l}\text { Serum } \\
\text { creat. }\end{array}$ & BUN & $C^{\prime} 3$ & $\begin{array}{c}\% \mathrm{P} \\
\text { undigested }\end{array}$ & $\begin{array}{c}\% \mathrm{P} \\
\text { digested }\end{array}$ & $\begin{array}{c}\text { Diff. in } \\
\% \mathrm{P}\end{array}$ & $\begin{array}{c}\text { Relative } \\
\text { change } \\
\text { in } P\end{array}$ & $P$ \\
\hline & & - & $\begin{array}{c}g \\
N e g\end{array}$ & $m g / 100 m l$ & $\begin{array}{c}m g / 100 ~ m l \\
9\end{array}$ & $\begin{array}{c}m g / 100 ~ m l \\
170\end{array}$ & $143+0.2$ & $14.9+0.1$ & 06 & $42 \%$ & $>0.05$ \\
\hline $\begin{array}{l}1 \\
2\end{array}$ & $\begin{array}{l}\text { Neg } \\
\text { Neg }\end{array}$ & - & $\begin{array}{l}\text { Neg } \\
\text { Neg }\end{array}$ & $\begin{array}{l}0.1 \\
1.0\end{array}$ & $\begin{array}{r}9 \\
14\end{array}$ & 102 & $\begin{array}{r}14.0 \pm 0.2 \\
4.7 \pm 0.4\end{array}$ & $\begin{array}{r}4.6 \pm 0.7\end{array}$ & $\begin{array}{r}0.0 \\
-0.1\end{array}$ & $-2.1 \%$ & $>0.05$ \\
\hline 3 & Neg & - & Neg & 1.1 & NA & 145 & $49.8 \pm 1.2$ & $48.9 \pm 0.8$ & -0.9 & $-1.8 \%$ & $>0.05$ \\
\hline 4 & Neg & 一 & Neg & 1.1 & 18 & 180 & $22.3 \pm 0.4$ & $22.4 \pm 0.5$ & 0.1 & $0.4 \%$ & $>0.05$ \\
\hline 5 & Neg & - & Neg & NA & NA & 115 & $15.6 \pm 0.4$ & $16.2 \pm 0.1$ & 0.6 & $3.8 \%$ & $>0.05$ \\
\hline
\end{tabular}


TABLE IV

Representative Changes in Binding of ${ }^{125}$ I-DNA by

Sera from Patients with Non-SLE Nephritis

\begin{tabular}{llrrrr}
\hline & \multicolumn{4}{c}{ 125I-DNA-binding } \\
\cline { 3 - 6 } & $\begin{array}{c}\text { \% P corr } \\
\text { undigested }\end{array}$ & $\begin{array}{c}\text { \% P corr } \\
\text { digested }\end{array}$ & $\begin{array}{c}\text { Difference in } \\
\% \text { P corr }\end{array}$ & $P$ \\
\hline 1 & Membrano-Prolif GN* & $3.1 \pm 0.2$ & $3.8 \pm 0.3$ & 0.7 & $>0.05$ \\
2 & Chronic GN & $3.6 \pm 0.1$ & $4.5 \pm 0.3$ & 0.9 & $>0.05$ \\
3 & Chronic GN & $2.2 \pm 0.4$ & $2.7 \pm 0.2$ & 0.5 & $>0.05$ \\
4 & Acute GN & $4.8 \pm 0.3$ & $4.5 \pm 0.3$ & -0.3 & $>0.05$ \\
5 & Subacute GN & $4.3 \pm 0.4$ & $5.0 \pm 0.3$ & 0.7 & $>0.05$ \\
\hline
\end{tabular}

* Glomerulonephritis.

an apparent decrease in DNA-binding during this acute exacerbation, but after DNase digestion the anti-DNA level did go up during the acute phase. In addition, the greatest rise in binding after digestion occurred during the severest stage of the exacerbation. Although permission for a renal biopsy could not be obtained, this patient had no clinical evidence of renal abnormality as judged by normal urinalysis, creatinine clearance, BUN, and serum creatinine.

\section{DISCUSSION}

It has been previously shown that DNase would dissolve the precipitate formed when DNA was added in vitro to SLE sera containing DNA antibodies. The resultant solution contained active DNA antibody which had been bound in the precipitate to the added DNA (16). Thus it was known that DNase could release anti-DNA antibody from DNA: anti-DNA complexes. It therefore seemed logical to DNase digest SLE sera suspected of containing such complexes. Evidence of increased DNA antibody after such treatment would indicate that the antibody must have been at least partially blocked by DNA in vivo, i.e., that soluble DNA : anti-DNA complexes were present.

An assay was devised to examine this possibility and control experiments showed that under the conditions

\section{TABLE V}

Representative Changes in Binding of ${ }^{125} I-D N A$ by Normal Controls

\begin{tabular}{ccccc}
\hline & \multicolumn{4}{c}{ 125I-DNA-binding } \\
\cline { 2 - 5 } Sera & $\begin{array}{c}\text { \% P corr } \\
\text { undigested }\end{array}$ & $\begin{array}{c}\text { \% P corr } \\
\text { digested }\end{array}$ & $\begin{array}{c}\text { Difference in } \\
\text { \% P corr }\end{array}$ & $P$ \\
\hline 1 & $4.0 \pm 0.2$ & $4.5 \pm 0.2$ & 0.5 & $>0.05$ \\
2 & $1.8 \pm 0.4$ & $3.1 \pm 1.0$ & 1.3 & $>0.05$ \\
3 & $5.1 \pm 0.2$ & $5.6 \pm 0.6$ & 0.5 & $>0.05$ \\
4 & $1.6 \pm 0.2$ & $2.5 \pm 0.1$ & 0.9 & $>0.05$ \\
5 & $7.1 \pm 0.4$ & $7.1 \pm 0.3$ & 0.0 & $>0.05$ \\
\hline
\end{tabular}

used one could free most of the DNA antibody bound in soluble DNA: anti-DNA complexes formed in vitro. Therefore, similar results could be expected with sera containing complexes formed in vivo.

RNase had no effect on an SLE serum which appeared to contain DNA : anti-DNA complexes-evidence of the specificity of this test. Thus the increase in binding, observed with certain SLE sera, must have been specifically due to the release of DNA antibody from DNA: antiDNA complexes.

The findings described in this paper show that DNA :anti-DNA complexes occur in some SLE sera at certain times, and there is often a correlation between the occurrence and amount of these complexes and renal disease activity. This relationship was most striking in those patients without significant chronic renal involvement, since renal function was normal before the acute exacerbation and returned to normal after it. There was also evidence of increased renal injury in those with an antecedent chronic lupus nephritis. In such patients, when the complexes disappeared from the circulation, renal function remained abnormal, often more abnormal than before the complexes were present. Presumably this was due to the fact that the chronically damaged kidneys had little or no reserve and the additional injury further increased their permanent functional disability.

TABLE VI

Mean Change in ${ }^{125}$ I-DNA-Binding for Each Group after DNase Digestion

\begin{tabular}{lcc}
\hline \multicolumn{1}{c}{ Group } & No. of sera & $\begin{array}{c}\text { Mean difference in } \\
\text { \% P corrected* }\end{array}$ \\
\hline Active SLE nephritis & 15 & $8.8 \pm 2.2$ \\
Inactive SLE & 13 & $0.3 \pm 0.2$ \\
Non-SLE nephritis & 18 & $0.2 \pm 0.2$ \\
Normal controls & 45 & $0.2 \pm 0.1$ \\
\hline
\end{tabular}

* Expressed as mean for all sera in group $\pm \mathrm{SE}$.

DNA:anti-DNA Complexes in SLE Sera 


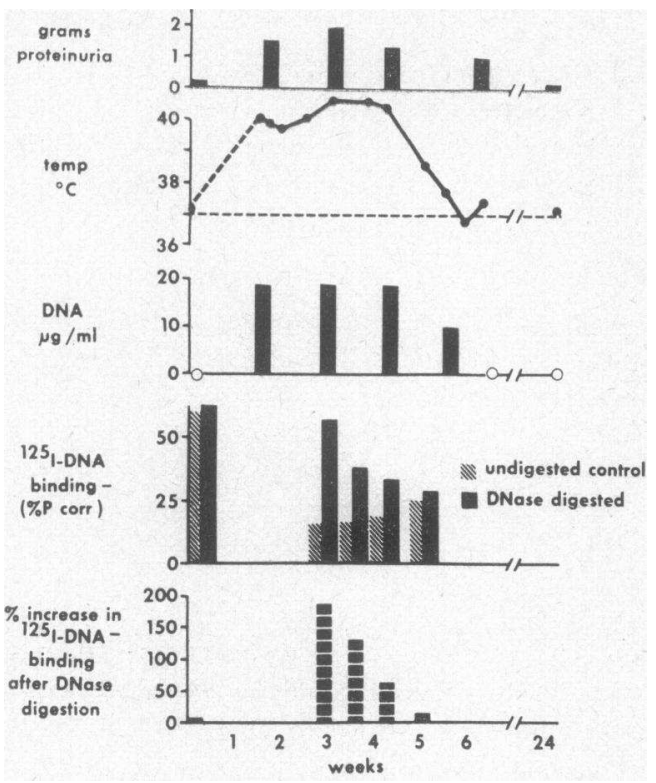

Figure 3 Course of a patient with an acute episode of SLE nephritis. The exacerbation was characterized by proteinuria and an elevated temperature. Concomitant with this was an increase in the binding of the serum to ${ }^{125} \mathrm{I}$-DNA after DNase digestion.

It is also of considerable interest that one patient without clinical evidence of renal disease had complexes in her circulation at the time she developed acute cerebritis. Unfortunately, this was a retrospective study and cerebrospinal fluid was not examined for complexes. There may be several reasons for the apparent lack of renal disease. It appears that considerable complex deposition can occur in the kidneys before clinical abnormalities in renal function. Immunoglobulins and complement have been found in the glomerular mesangium without alteration in glomerular function (17). The mesangium may generally be the initial site of localization of complexes, with an accumulative increase until an overflow along the basement membrane occurs resulting in clinical renal disease. This patient's first symptoms of SLE occurred only 5 mo before the acute episode described. Significant lupus nephritis often does not occur until one or more years after the initial symptoms of the disease $(17,18)$, possibly because the deposition of complexes in the kidneys has been insufficient to cause abnormal function. Another possibility is that the nature of the complexes plays an important role in their deposition. That is, certain antigen-antibody complexes, because of the characteristics of the antigen, the antibody, and/or the combination tend to deposit in some sites more readily than in others. Perhaps most likely, a number of factors all contribute to how soon and how severely renal disease occurs. It would have been of great interest to examine her renal tissue, but permission for a biopsy could not be obtained.

It is important to note several features of the results obtained. First is the observation that the DNAbinding level was higher in sera from certain patients with inactive disease than it was in sera from some pa. tients with active disease (Tables If and III). Although this finding might initially seem contradictory, it may simply show the necessity of immune complex formation for the development of pathologic changes, since none of the inactive patients had demonstrable DNA:antiDNA complexes. Second, even though a correlation was found between the increased DNA-binding after DNase digestion and renal disease activity in eight of the nine serial studies performed, sera from certain patients with active nephritis showed no evidence of DNA : anti-DNA complexes (e.g., active disease sera 9 and 10 in Table II). These two patients had normal C3 levels, which might suggest their renal disease was due tơ a noncomplement-dependent mechanism or was a chronic rather than acute condition without added injury occurring at the time of our study. Furthermore, other antigen-antibody complexes are almost certainly involved in the pathogenesis of lupus nephritis. The assay described was capable of detecting only DNA: anti-DNA complexes. Although DNA has been the only extrinsic antigen identified in the renal basement membrane thus

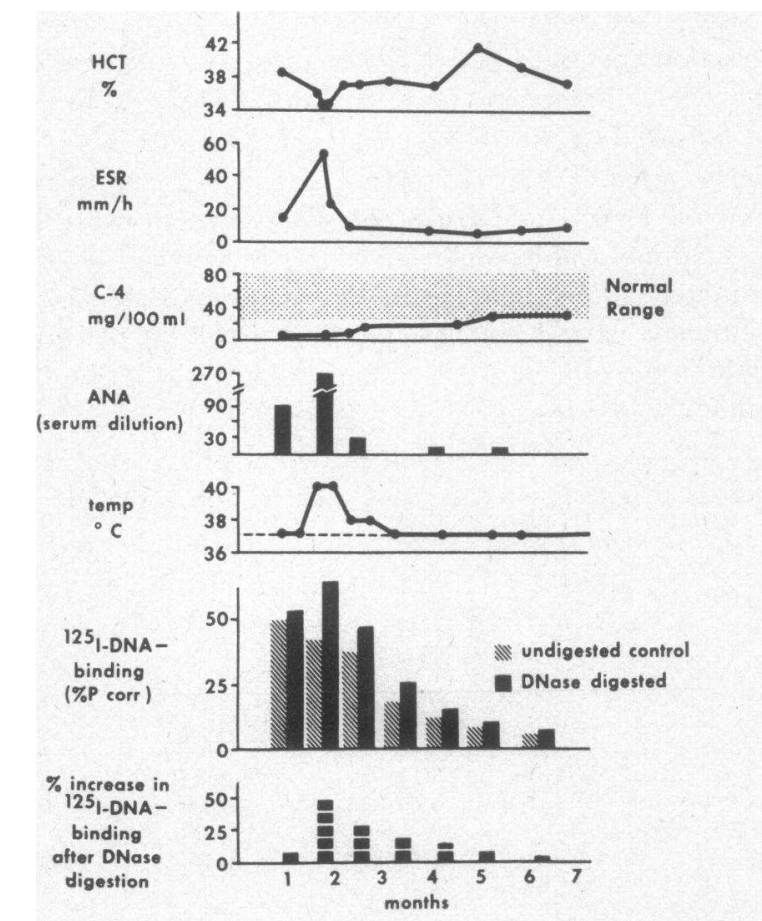

Figure 4 Serial study on a patient with SLE cerebritis. DNA : anti-DNA complexes were evident during the disease exacerbation. 
far, antinucleoprotein and antiribonucleoprotein antibodies have been eluted from SLE glomeruli $(3,19)$. In addition. of interest in this regard is the recent description of anti-BGG and anti-bovine serum albunin antibodies in the sera of some patients with SLE and the occurrence of a BGG-like material in the sera of certain patients $(20)$.

Of prime interest in regard to the DNA: anti-DNA complexes is the origin of the DNA. Although it has been suggested that the DNA may be of endogenous origin (1), the same authors stated that without full characterization of the DNA, the possibility that it might be of exogenous origin could not be excluded. Recently, preliminary studies have suggested that in at least some cases the DNA is in fact of exogenous origin since protein-free DNA isolated from five SLE sera was found to have a different buoyant density from that of normal human DNA (21).

\section{ACKNOWLEDGMENTS}

We thank Dr. H. G. Kunkel, The Rockefeller Lniversity, and Dr. M. Hutt, University of Colorado Medical Center, for providing sera used in these studies. We wish to acknowledge the excellent technical assistance of Nancye Files and Andree Hoffman.

This investigation was supported in part by Grants AI09481, AI-10872, and AI-00409 from the National Institutes of Health.

\section{REFERENCES}

1. Tan, E. M., P. H. Schur, R. I. Carr, and H. G. Kunkel. 1966. Deoxyribonucleic acid (DNA) and antibodies to DNA in the serum of patients with systemic lupus erythematosus. J. Clin. Invest. 45: 1732.

2. Carr, R. I. 1969. DNA antibodies and DNA in serum. Ph.D. Thesis. The Rockefeller University, New York. 54.

3. Koffler, D., P. H. Schur, and H. G. Kunkel. 1967. Immunological studies concerning the nephritis of systemic lupus erythematosus. J. Exp. Med. 126: 607.

4. Koffler, D., V. Agnello, R. Thoburn, and H. G. Kunkel. 1971. Systemic lupus erythematosus: Prototype of immune complex nephritis in man. J. Exp. Med. 134: 169s

5. Natali, P. G., and E. M. Tan. 1972. Experimental renal disease induced by DNA-anti-DNA immune complexes. J. Clin. Invest. $51: 345$.

6. Cochrane, C. G. 1967. Discussion after evidence for the renal deposition of antigen-antibody complexes in patients with systemic lupus erythematosus. In Immunopathology, Vth International Symposium. P. A. Miescher and P. Grabar, editors. Grune and Stratton, Inc., New York. 78.

7. Broder, I., R. Baumal, and F. Keystone. 1968. Studies into the occurrence of soluble antigen-antibody complexes in disease. II. Criteria for distinguishing soluble complexes from other macromolecular histamine releases. Clin. Exp. Immunol. 3: 537.

8. Agnello, V.. D. Koffler, J. W. Eiscnberg, R. T. Winchester, and H. G. Kunkel. 1911. Clq precipitins in the sera of patients with systemic lupus erythematosus and other hypocomplementemic states: Characterization of high and low molecular weights types. J. E.rp. Med. $134: 228 \mathrm{~s}$

9. Christian, C. L., L. B. Hanauer, and T. Pincus. 1967. Systemic lupus erythematosus-Immune complex disease? In Immunopathology, Vth International Symposium. P. A. Miescher and P. Grabar, editors. Grune and Stratton, Inc., New York. 83.

10. Pace, B., and N. R. Pace. 1971. Gene dosage for 5S ribosomal ribonucleic acid in Escherichia coli and Bacillus megatcrium. J. Bacteriol. 105: 142.

11. Commerford, S. L. 1971. Iodination of nucleic acids in vitro. Biochemistry. 10: 1993.

12. Wold, R. T, F. E. Young, E. M. Tan, and R. S. Farr 1968. Deoxyribonucleic acid antibody: A method to detect its primary interaction with deoxyribonucleic acid. Science (Wash. D. C.). 161: 806.

13. Minden, P., and R. S. Farr. 1967. The ammonium sulfate method to measure antigen-binding capacity. In Handbook of Experimental Immunology. D. M. Weir, editor. Blackwell Scientific Publications Ltd., Oxford, England. 463.

14. Fisher, R. A. 1950. Tests of significances of means, differences of means, and regression coefficients. In Statistical Methods for Research Workers. Oliver and Boyd Ltd., Edinburgh. 2nd edition. 114.

15. Siegal, S. 1956. The case of two independent samples. In Nonparametric Statistics for the Behavioral Sciences. McGraw-Hill Book Company, Inc., New York. 95.

16. Deicher, H. R. G., H. R. Holman, and H. G. Kunkel. 1959. The precipitin reaction between DNA and a serum factor in systemic lupus erythematosus. J. Exp. Med. 109: 97.

17. Koffler, D., V. Agnello, R. I. Carr, and H. G. Kunkel. 1969. Variable patterns of immunoglobulins and complement deposition in the kidneys of patients with systemic lupus erythematosus. Am. J. Pathol. 56: 305.

18. Comerford, F. R., and A. S. Cohen. 1967. The nephropathy of systemic lupus erythematosus. Medicine (Baltimore ). 46: 425 .

19. Krishnan, C., and M. H. Kaplan. 1967. Immunopathologic studies of systemic lupus erythematosis. II. Antinuclear reaction of $\gamma$-globulin eluted from homogenates and isolated glomeruli of kidneys from patients with lupus nephritis. J. Clin. Invest. 46: 569.

20. Carr, R. I., R. T. Wold, and R. S. Farr. 1972. Antibodies to bovine gamma globulin (BGG) and the occurrence of a BGG-like substance in systemic lupus erythematosus sera. J. Allergy Clin. Immunol. 50: 18.

21. Fudenberg, H. H., and H. R. Holman (Chairmen). 1971. Autoimmune diseases; genetics, mechanisms and diagnostic approaches, Workshop 36. In Progress in Immunology, Proceedings of the First International Congress of Immunology. B Amos, editor. Academic Press Inc., New York. 1321 